\title{
Study of physico-chemical factors affecting the growth of cell-culture adapted bovine Rotavirus strain of Pakistan
}

\author{
Wardah Sharmeen Syed ${ }^{\star \#}$, Nadia Mukhtar, Nauman Zahid and Tahir Yaqoub\# \\ University of Veterinary and Animal Sciences, Lahore, Pakistan. \\ *Corresponding authors. Email: tahiryaqub@uvas.edu.pk \\ \#These authors contributed equally to this work.
}

\begin{abstract}
Copyright $@ 2019$ Syed et al. This article remains permanently open access under the terms of the Creative Commons Attribution License 4.0, which permits unrestricted use, distribution, and reproduction in any medium, provided the original work is properly cited.
\end{abstract}

Received 15th January, 2019; Accepted 4th March, 2018

\begin{abstract}
Rotavirus (RV) diarrhea is the major cause of death of millions of children in developing countries besides causing economically significant malady in neonates of many domestic animals. There is a very little information available for the factors which can affect prevalence of Bovine Rotavirus (BRV) in Pakistan. There is a dire need to propagate BRV on cell culture and evaluate the physical and chemical control of RV in effective ways for the betterment of human and livestock welfare. Therefore, the present study aimed to propagate BRV on Madin-Darby bovine kidney (MDBK) cell line. The screening of the virus was done by using commercially available kit and TCID 50 technique. The propagation of BRV was then led to study its inactivity and infectivity potential using different physical and chemical factors. For this reason, 3 physical factors (Temperature, $\mathrm{pH}$ and UV light) and 8 chemical disinfectants were used. The virus got completely inactive at a temperature range of 75 to $80^{\circ} \mathrm{C}$ and 5.00 to $6.00 \mathrm{pH}$ while remained active at 7.04 and 8.00 . The virus was inactivated after exposure to $0.5 \%$ Virkon $^{\circledR}$-S within 30 minutes, $0.5 \%$ Bromo-Sept after 30 min, and $1.0 \%$ surf excel after 30 min Phenol within $60 \mathrm{~min}$ at a concentration of $1.0 \%$ and $0.6 \% \mathrm{H}_{2} \mathrm{O}_{2}$ after $30 \mathrm{~min}$ proved to be virucidal for the virus. These findings can be helpful for the farmers to keep their farms decontaminated from this virus. Moreover, these results can also be of help in the prevention of the outbreaks that occur in the hospitals.
\end{abstract}

Keywords: Bovine Rotavirus, cell culture, chemical factors, culturing of BRV, physical factors.

\section{INTRODUCTION}

Rotavirus, a leading source of gastroenteritis in humans and animals, causes diarrhea in young calves (Swiatek et al., 2010). Bovine Rotavirus (BRV) is responsible for neonatal calf diarrhea and it has been perceived in both beef cattle and dairy all over the world (Holland, 1990) and contribute considerably to diarrhea and enteritis in competently nurtured neonatal calves (Dhama et al., 2009). Neonatal diarrhea represents an imperative hygiene problem in livestock production which causes an extremely negative economic influence related to veterinary treatment costs, reduction in weight gain of affected animals and death (Badaracco et al., 2013). It is non-enveloped, icosahedral shaped, triple-layered symmetry virus belonging to the family Reoviridae (Aiyegbo et al., 2014). Group A Rotaviruses are intestinal pathogens that cause infection in the young of nearly every mammalian and avian species. They replicate in enterocytes of the intestinal tract which leads to severe gastroenteritis and later viruses shed into the stool (Arnold et al., 2009).

In 2007, National Animal Health Monitoring System for U.S. dairy declared that diarrhea causes $50 \%$ of the mortality in un-weaned calves and most of it occurred in calves of less than 1 month of age. Neonatal calf mortality varies from 8.7 to $64 \%$ throughout the world constituting $84 \%$ of the total mortality in the first month of age and is particularly high in the third week (Cho, 2012). Annually Rotavirus kills approximately half a million bovines globally and among these estimated deaths around one-third ( $N=160,000$ deaths) occur in the Indian subcontinent (Chen et al., 2012). Moreover, three countries Bangladesh, 
India, and Pakistan in the Indian subcontinent form $>30 \%$ ( $N=160,000$ to 200,000$)$ of all the deaths related to Rotavirus all over the world (Miles et al., 2012).

Rotaviruses show considerably good growth in Vero and MDBK cells, and so testing for them is of particular importance (Gregersen, 2012). Different studies on BRV had been carried out on monkey, mouse, and human cell lines (Bugarčić and Taylor, 2006; Kaushik et al., 2008). Even though a clear information regarding these heterologous cell culture models might not completely relate to cattle given known differences in Rotavirus strains, cellular receptors, species barriers, and other factors which are required for Rotavirus infectivity, uptake, pathogenesis and replication (Estes et al., 2001; Lopez and Arias, 2006; Pesavento et al., 2006; Ramig, 2004). For infecting the cells provided, the virus must enter the plasma membrane of the host cell and this needs good penetration ability. The ability to penetrate the cell is increased by the use of proteolytic enzymes (Arias et al., 2002). Antigen capture enzymelinked immunosorbent assay (ELISA), reverse transcription-PCR (RT-PCR) and latex agglutination are the methods which have become standard for the detection and analysis of bovine Rotavirus infections (Maes et al., 2003 and Al-Robaiee and Al Farwachi, 2013).

Rotaviruses are mainly pervasive in farm animals. Different viruses vary significantly in liability to treatment with high pressure and this distinction can be attributed to the diversity of the structural morphology of virus (Smelt, 1998; Khadre and Yousef, 2002). Heating at $50^{\circ} \mathrm{C}$ for 30 min inactivates $99 \%$ of the virus infectivity (Estes et al., 1979). A number of antibiotics and chemical disinfectants are commonly used to avert and regulate the dissemination of viral diseases in hospitals, laboratories and many other institutional or domestic settings (Höh et al., 1983).

Thus, the objective of the study is to draw an emphasis towards the study of such physical and chemical factors which can help in eliminating Rotavirus from the premises of the farms and from the healthy animals and if by chance an animal encounters with rotavirus then the removal of the virus from the animal body can be done by using easy and cheap methods.

\section{MATERIAL AND METHODS}

Bovine Rotavirus (BRV) was collected from a diarrheic calf which was injected with the Rotavirus once procured from the seed bank of Quality Operations Laboratory, University of Veterinary and Animal Sciences, Lahore. The samples of intestine and blood of infected calf were used to isolate the virus.

\section{Screening of positive sample}

The screening of bovine rotavirus antigen from faecal supernatant was done by using commercially available antigen capture ELISA kit (Cypress Diagnostics, Belgium).

\section{Cell culture adaptation}

MDBK cells were grown in the laboratory using Dulbecco's Minimum Essential Medium (DMEM) and F12 supplemented with $10 \%$ of Fetal Bovine Serum (FBS). BRV was propagated in cell culture after treatment with porcine trypsin $1 X(10 \mu \mathrm{g} / \mathrm{ml}$; Sigma-Aldrich) for 30 to $60 \mathrm{~min}$ at $37^{\circ} \mathrm{C}$. Two (2) $\mathrm{ml}$ of the virus suspension was poured into the flask and let it adsorbed by the cells of the monolayer for 2 to 4 hours at $37^{\circ} \mathrm{C}$. Later the suspension was discarded and the cells were filled with 15 to $20 \mathrm{ml}$ of the serum free medium (DMEM w/o serum with $100 \mu \mathrm{g} / \mathrm{ml}$ streptomycin, $100 \mathrm{l} . \mathrm{U} / \mathrm{ml}$ penicillin-G and $2.5 \mathrm{\mu g} / \mathrm{ml}$ amphotericin-B) (Reading et al. 1998, Arias et al. 2002).

Then, the flask was incubated for a period of 72 hours in $\mathrm{CO}_{2}$ incubator at $37^{\circ} \mathrm{C}$. After visualizing the initial appearance of cytopathic effects (CPEs), namely degeneration, cytoplasmic vacoulation and the development of eosinophilic intracytoplasmic inclusions (McNulty, 1978), the flask was re-incubated at $37^{\circ} \mathrm{C}$ in $5 \%$ $\mathrm{CO}_{2}$ for another 3 to 4 days till complete appearance of CPEs (Figure 1a). At the terminal stage when maximum CPEs were evident as a complete detachment of the cell monolayer (Figure $1 \mathrm{~b}$ ), the flasks were placed at $-80^{\circ} \mathrm{C}$ for $10 \mathrm{~min}$. The flasks were taken out and placed at room temperature till complete thawing of the flask content. The flasks were subjected to two freeze-thaw cycles in the similar manner. At the end, the entire harvested medium was centrifuged at $4000 \mathrm{rpm}$ for a period of $10 \mathrm{~min}$ in a refrigerated centrifuge machine at $4^{\circ} \mathrm{C}$ and supernatant was used as virus source for further experiments.

\section{Calculation of infectivity titers of BRV}

Biological titration of the harvested BRV as tissue culture infective dose 50 (TCID 50 ) was calculated by using the technique of Reed and Meunch (Swayne et al. 2006).

\section{Effect of physical factors on the survival of BRV}

The propagated virus particles were treated with three physical factors namely, Temperature $\left(37,50\right.$ to $\left.80^{\circ} \mathrm{C}\right), \mathrm{pH}$ (5.00 to 12.00) and UV light with the wavelength of 253.7 $\mathrm{nm}$ for different time intervals. The grown virus was exposed under the mentioned conditions separately, to study the effect of each factor on the growth of the virus. Triplicate plates were also used for this purpose.

\section{Effect of conventional chemicals on the survival of BRV}

For this purpose, 4 conventional (laboratory used) chemicals were selected which included phenol, ethanol, isopropanol and $\mathrm{H}_{2} \mathrm{O}_{2}$. Formaldehyde was not used in this study as it was found to be cytotoxic to the cells. These chemicals were used with the concentrations as phenol ( 0.5 
(a)

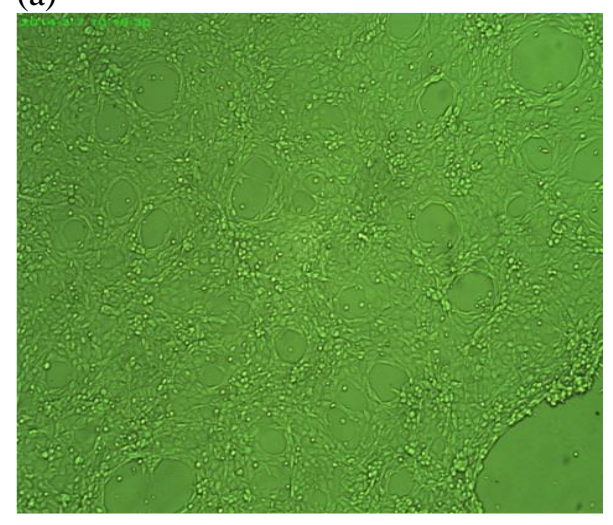

(b)

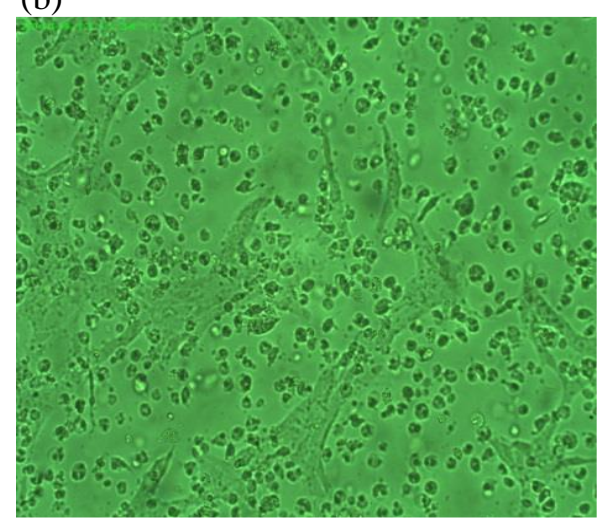

Figure 1. Cytopathic effects of Rotavirus; (a) Early stage of CPEs (Monolayer started detaching from the cell line) of bovine rotavirus on MDBK cells (b) Terminal stage; complete detachment of monolayer of rotavirus.

to $2.5 \%$ ), ethanol (60 to $98.5 \%$ ), isopropanol (60 to $90 \%$ ) and finally $\mathrm{H}_{2} \mathrm{O}_{2}(0.2$ to $1.0 \%)$ for $0,30,60,90$ and 120 min,respectively. The virus was exposed to these chemicals the same way as they were exposed to physical factors and then their titer was studied using TCID 50.

\section{Effect of commercial chemicals on the survival of BRV}

In order to study the effect of commercial products on BRV four types of disinfectants were used which includes Pyodine, Virkon ${ }^{\circledR}-\mathrm{S}$, Bromo-sept and surf excel with the concentrations of $0.5,1.0$ and $2.0 \%$ for each and for the time interval of $0,30,60,90$ and 120 min for each of the chemical concentration employed.

\section{RESULTS}

\section{Bovine rotavirus on MDBK cell line}

The monolayer formed was given infection with the procured and screened bovine Rotavirus by the procedure described previously. CPEs were observed after 5 days but the terminal stage of the CPEs was obtained after 8 days of incubation under standard conditions as shown in Fig 1.

From the viral stock, biological titer was calculated by using Reed and Muench formula (Swayne et al., 2006) by observing the CPEs and scoring the wells positive or negative according to the effects imposed on the cells by the virus. The titer came out to be $10^{6.62} / 1 \mathrm{ml}$ of BRV with $50 \%$ endpoint dilution.

\section{Effect of physical factors on BRV}

\section{Effect of temperature}

The virus was kept at the normal temperature range $\left(37^{\circ} \mathrm{C}\right)$ and the elevated temperature ranges $\left(50\right.$ to $80^{\circ} \mathrm{C}$ ) using the electrical water bath. The effect of different temperatures on the infectivity titers of BRV as recorded at various time intervals was checked three times by using the technique of TCID 50 as described in the previous section and shown in Table 1 which shows that the virus was able to grow at $37^{\circ} \mathrm{C}$ which was a favourable temperature for its growth, but the growth of the virus was abolished as the temperature was raised.

\section{Effect of $\mathrm{pH}$ on the survival of $\mathrm{BRV}$}

The effect of three pH values 5.00, 6.00 (acidic), 7.40 near to neutral as available in biological system, and 8.00 to 12.00 (alkaline) conditions for survival of BRV was determined and results are given in Figure 2(a,b). The virus started showing depletion at $\mathrm{pH} 6$ and was found completely destroyed at $\mathrm{pH} 5.0$ having the mean standard deviation of $3.09 \pm(0.035)^{\mathrm{b}}$ after $120 \mathrm{~min}$. Whereas, BRV showed stunted growth again at $\mathrm{pH} 12.0$ having the mean standard deviation of $2.75 \pm(0.070)^{\mathrm{b}}$ after $120 \mathrm{~min}$. The virus remained unaffected at $\mathrm{pH} 7.40$.

\section{Effect of UV light on the infectivity of BRV}

Exposure of the virus by UV light had been carried out at the wavelength of $253.7 \mathrm{~nm}$ for different time intervals keeping the same wavelength. UV light showed a very clear decrease in the titer of BRV. BRV started getting inactive after $30 \mathrm{~min}$ with the mean standard deviation value of $3.47 \pm(0.028)^{\mathrm{b}}$ and was completely destroyed in 3 hours exposure of UV light with the mean standard deviation value of $000 \pm(0.00)$ as represented by Figure 3 .

\section{Evaluation of conventional chemical factors on the survival of BRV}

\section{Effect of phenol on the infectivity of BRV}

To evaluate the inactivation potential of the phenol to $B R V$, 


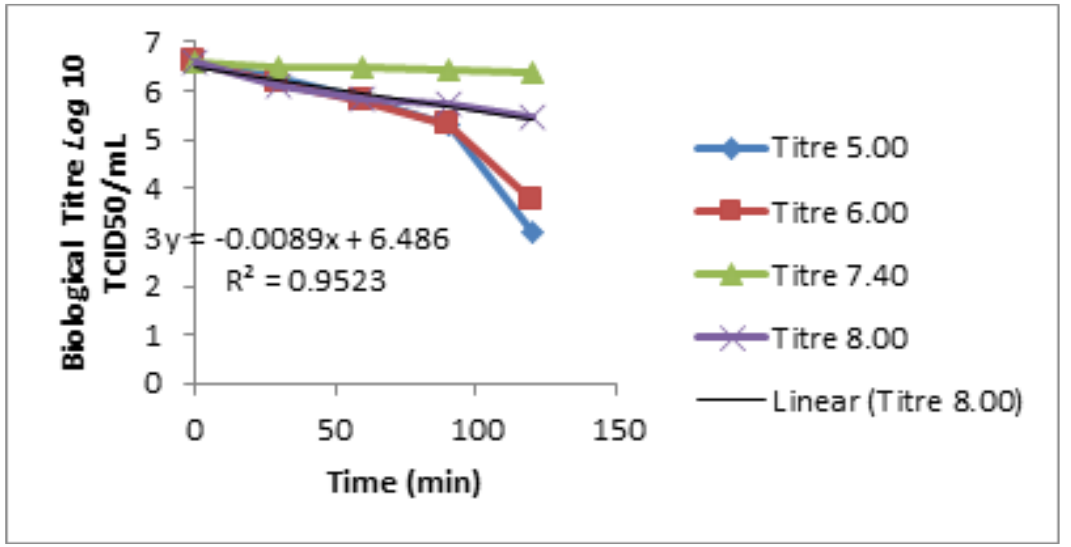

Figure 2(a). Linear regression model showing decrease in titer of BRV after exposure to $\mathrm{pH}$ 5.00-8.00 conditions.

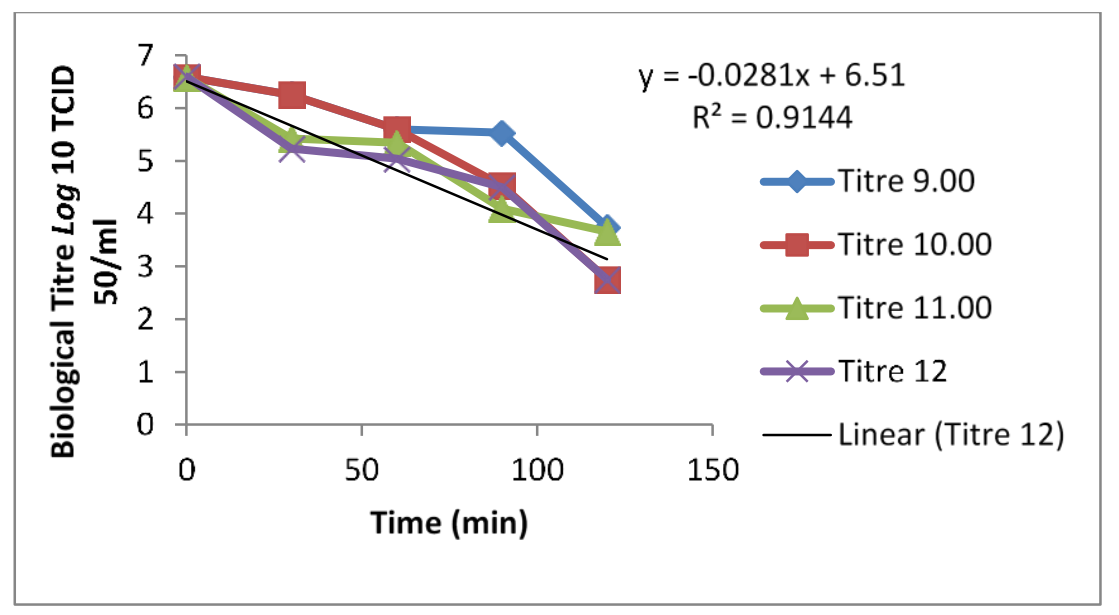

Figure 2(b). Linear regression model showing decrease in titer of BRV after exposure to $\mathrm{pH}$ 9.00-12.00 conditions.

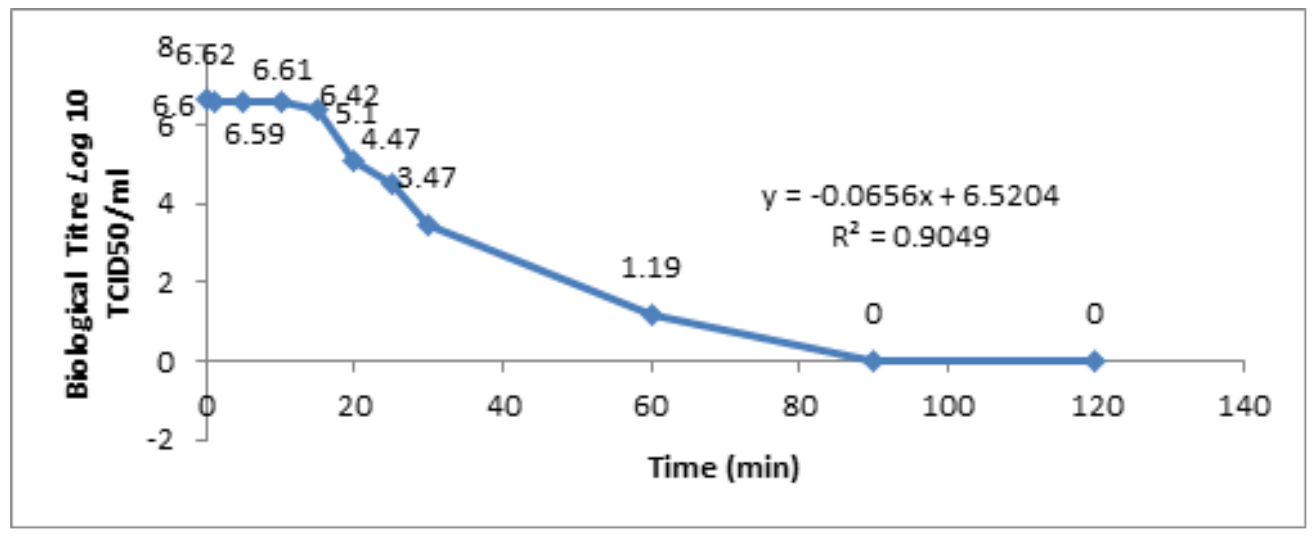

Figure 3. Linear regression model showing decrease in titer of BRV after exposure to UV light.

0.5 to $2.5 \%$ solution was prepared and then evaluated for anti-viral activity against BRV. Recommended concentration of phenol for disinfection $2.5 \%$ and $3.0 \%$ were found to be highly cytotoxic so a much diluted concentrations used on cell culture. The decline growth pattern can be seen from Figure $4(a, b, c)$. 


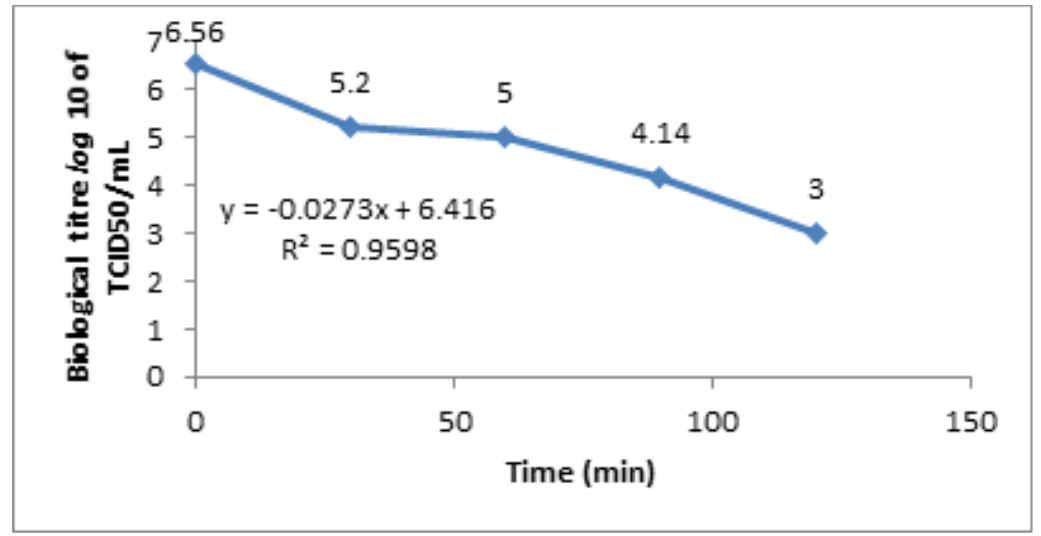

Figure 4(a). Linear regression model showing decrease in titer of BRV by treatment with $0.5 \%$ Phenol.

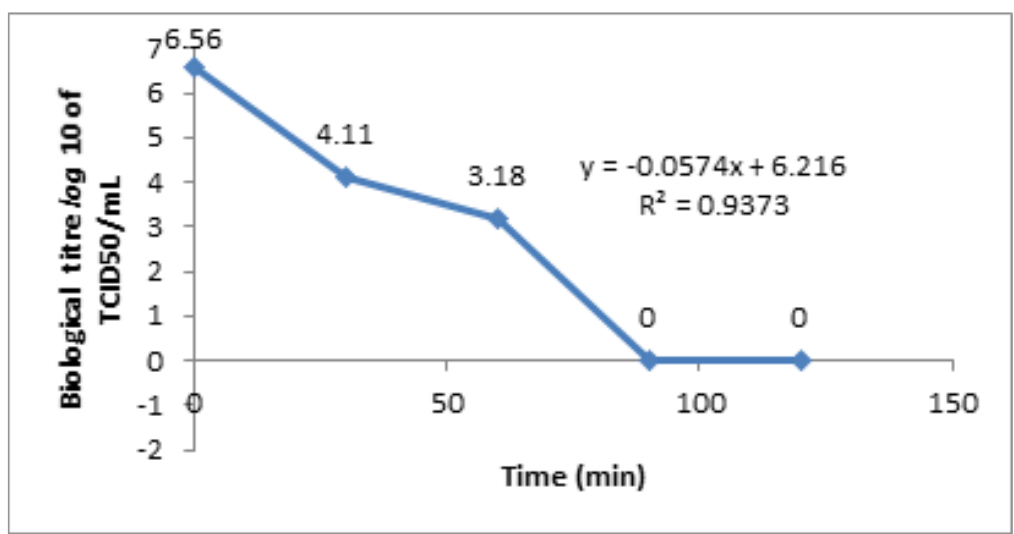

Figure 4(b). Linear regression model showing decrease in titer of BRV by treatment with $1.0 \%$ Phenol.

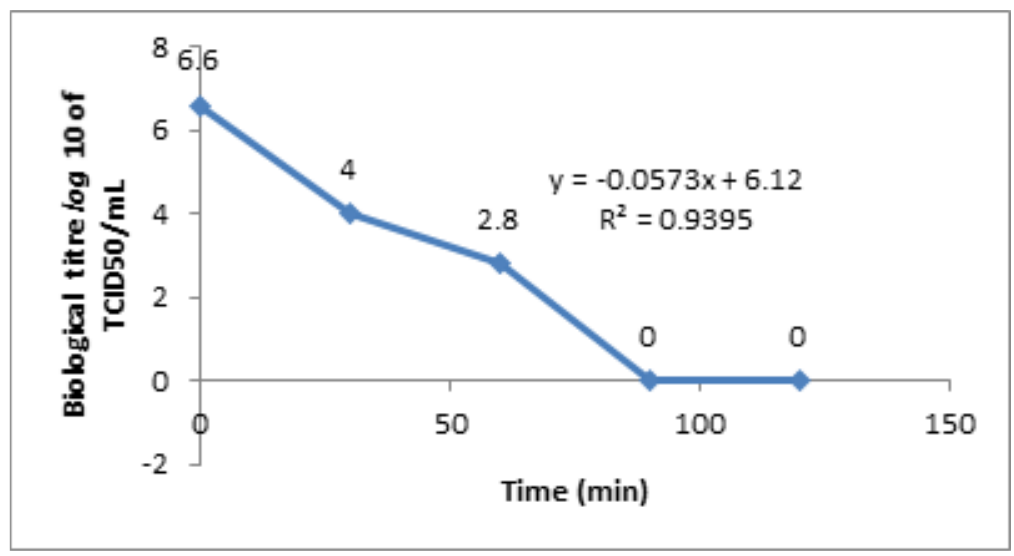

Figure 4(c). Linear regression model showing decrease in titer of BRV by treatment with $1.5 \%$ Phenol.

\section{Effect of ethyl alcohol on the survival of BRV}

To study the effect of ethanol, five concentrations $(60,70$,
80, 90 and 98.5\%) were studied. Recommended concentrations of ethanol 80 and $90 \%$ were found cytotoxic for BRV for the interval of $\mathbf{3 0}$ min so absolute alcohol was 


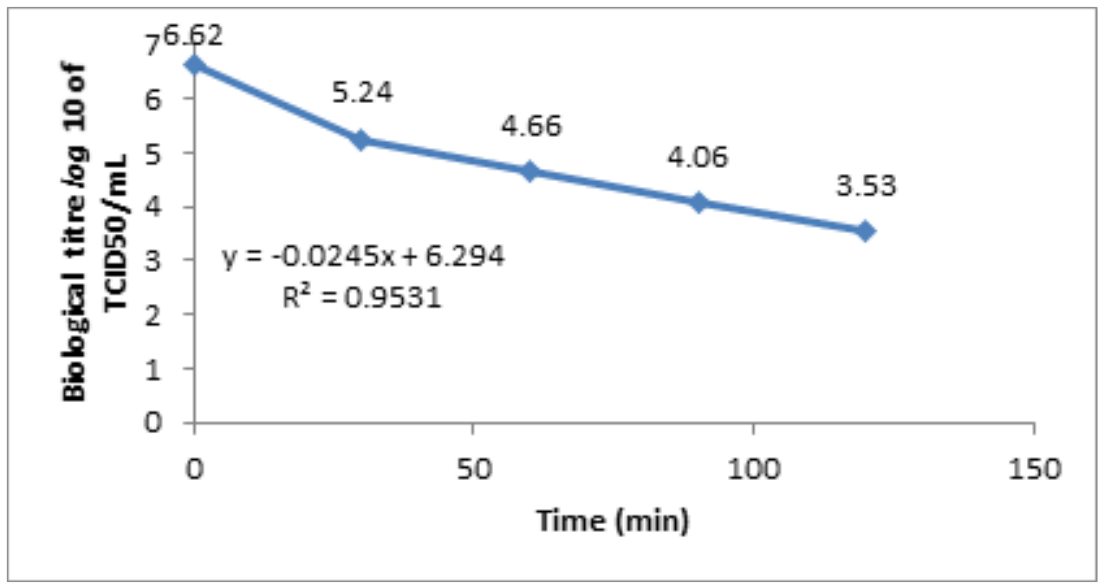

Figure 5(a). Linear regression model showing decrease in titer of BRV by treatment with $60 \%$ ethanol.

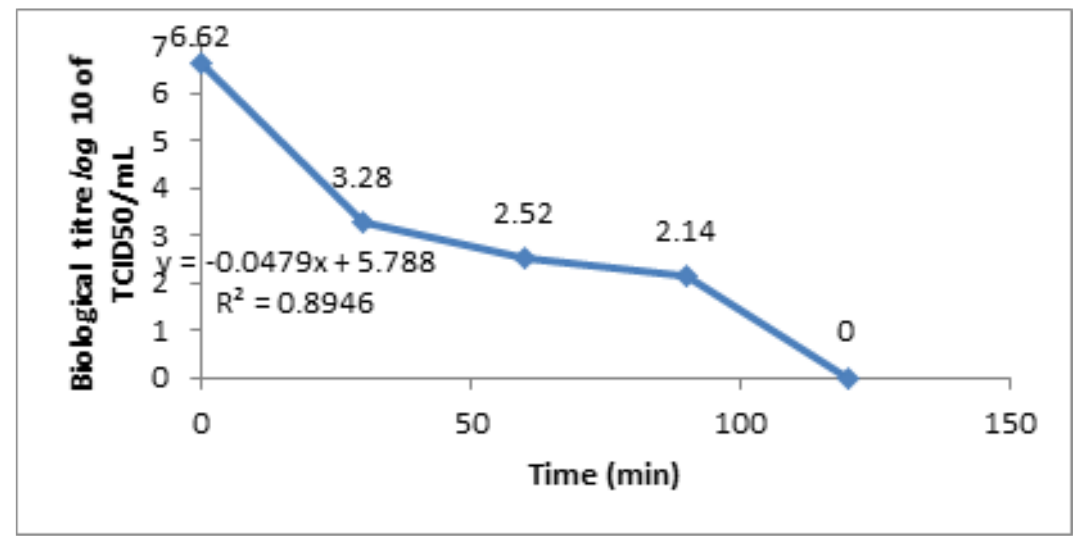

Figure 5(b). Linear regression model showing decrease in titer of BRV by treatment with $70 \%$ ethanol.

diluted to the extent of $60 \%$ to study its effect on the monolayer of the BRV. As shown in Figure 5(a, b), it can be seen that a dilution of $60 \%$ the virus still had somewhat smooth growth, whereas it started having stunted growth at $70 \%$ after $60 \mathrm{~min}$.

\section{Effect of Isopropanol on the survival of BRV}

In order to study the effect of isopropanol, four concentrations $(60,70,80$ and $90 \%)$ were studied. It has been stated that with the increasing concentration of the alcohol used, the reduction in the titer of the virus is significant (Kurtz et al., 1980), so for this reason BRV was given trial with the increasing concentration of alcohol with 3 carbon atoms (isopropanol) and studied its impact on the activity of the virus for varying time intervals. Recommended concentrations of Isopropanol 80 and $90 \%$ were found cytotoxic for BRV for the interval of $30 \mathrm{~min}$ so diluted concentrations were used to study the effect on the growth as shown in Figure 6(a, b, c).

\section{Effect of Hydrogen Peroxide $\left(\mathrm{H}_{2} \mathrm{O}_{2}\right)$ on the survival of $B R V$}

The effect of $\mathrm{H}_{2} \mathrm{O}_{2}$ was studied on BRV using five concentrations $(0.2,0.4,0.6,0.8$ and $1.0 \%)$. BRV have been found to get inactivated by the use of $\mathrm{H}_{2} \mathrm{O}_{2}$ with the concentration of $1.0 \%$ (Meng et al. 1987). So, the local strain of $\mathrm{BRV}$ was exposed to varying time intervals to different concentrations of $\mathrm{H}_{2} \mathrm{O}_{2}$. The observations are shown in Figure $7(\mathrm{a}, \mathrm{b})$. The virus started showing stunted growth at $0.6 \%$ concentration of $\mathrm{H}_{2} \mathrm{O}_{2}$ after 90 minutes.

\section{Evaluation of commercial chemical factors on the survival of BRV}

\section{Effect of Pyodine on the survival of BRV}

To evaluate the inactivation potential of Pyodine (10\% solution of povidone-iodine) on BRV, three concentrations $(0.5,1.0$ and $1.5 \%$ were prepared of commercially available 


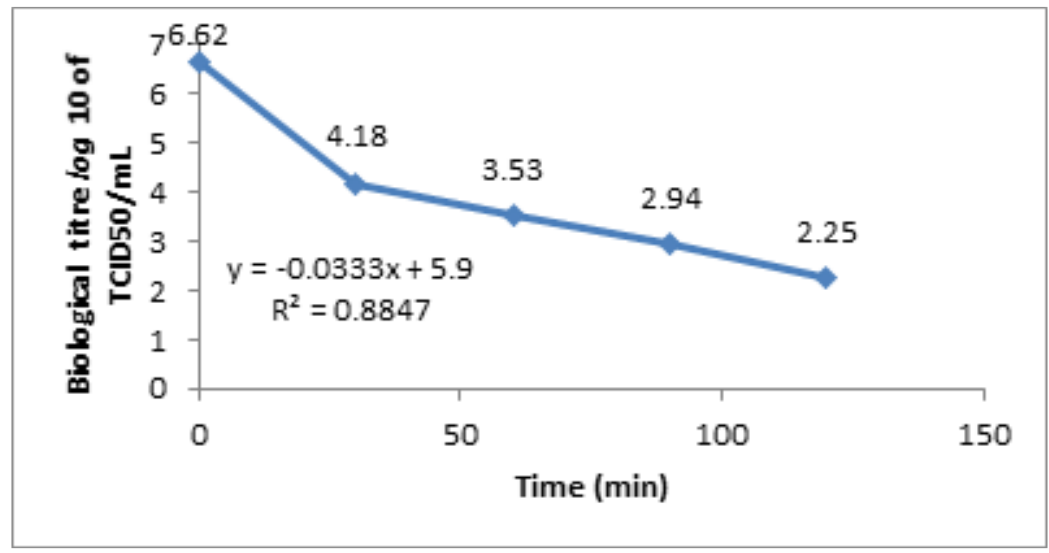

Figure 6(a). Linear regression model showing decrease in titer of BRV by treatment with $60 \%$ isopropanol.

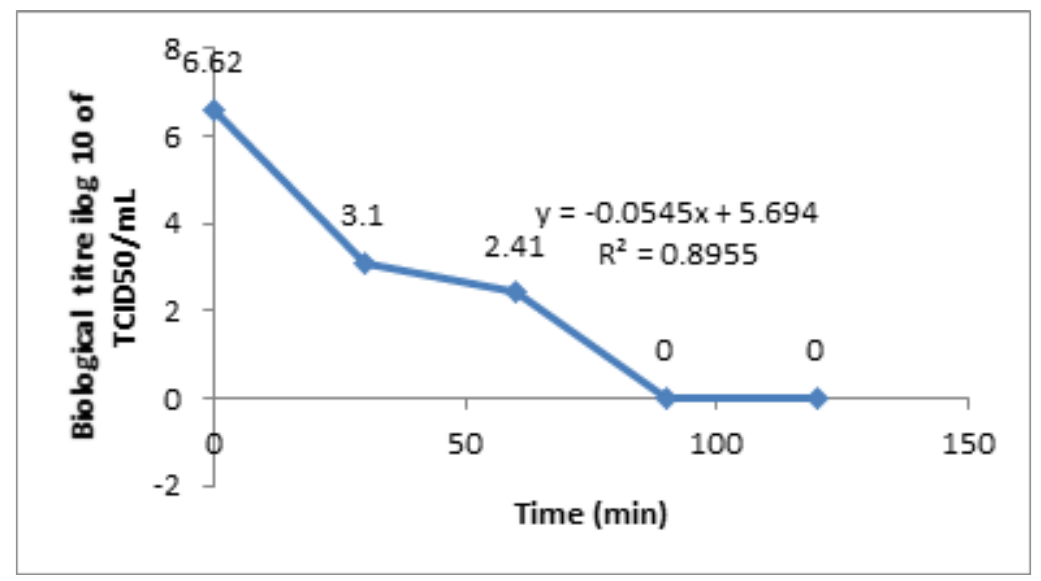

Figure 6(b). Linear regression model showing decrease in titer of BRV by treatment with $70 \%$ isopropanol.

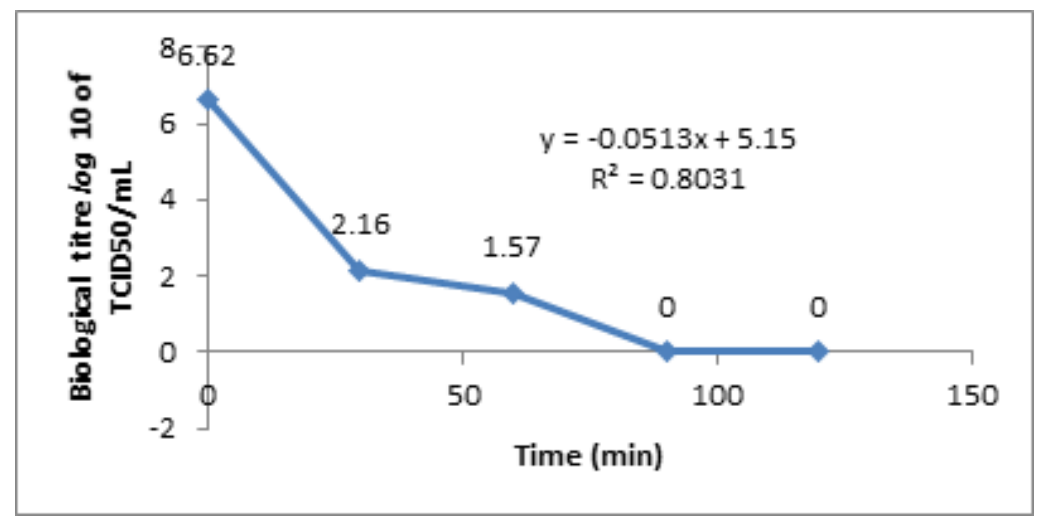

Figure 6(c). Linear regression model showing decrease in titer of BRV by treatment with $80 \%$ isopropanol.

$10 \%$ solution). The study was conducted at different time intervals in order to evaluate the cytotoxicity and viral inactivation potential if, however, occurred due to the use of this chemical (Figure 8a, b). At $1 \%$ concentration of pyodine, a decrease in the infectivity of the virus in the cells was observed after 90 min. 


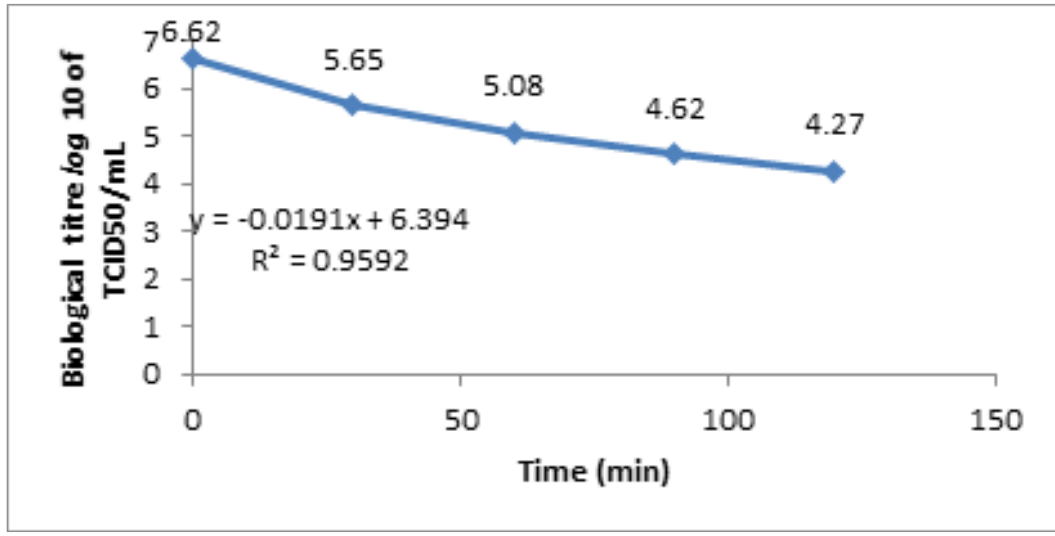

Figure 7(a). Linear regression model showing decrease in titer of BRV by treatment with $0.2 \% \mathrm{H}_{2} \mathrm{O}_{2}$.

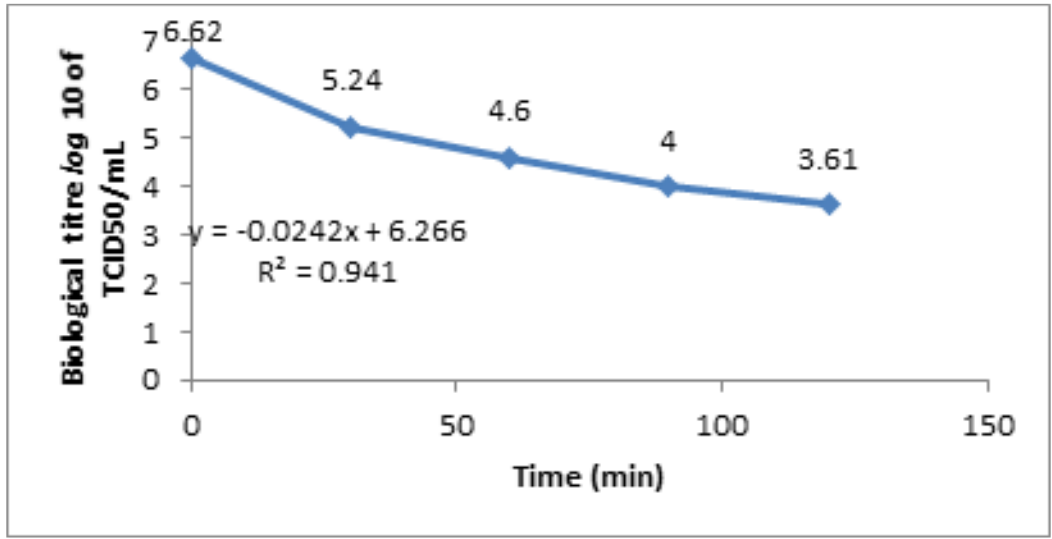

Figure 7(b). Linear regression model showing decrease in titer of BRV by treatment with $0.4 \% \mathrm{H}_{2} \mathrm{O}_{2}$.

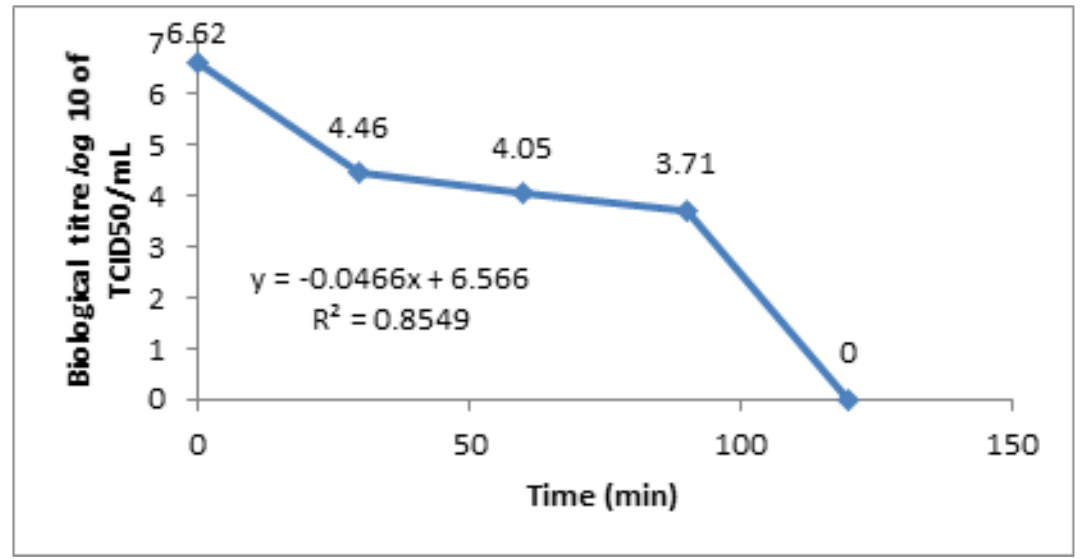

Figure 7(c). Linear regression model showing decrease in titer of BRV by treatment with $0.6 \% \mathrm{H}_{2} \mathrm{O}_{2}$.

Effect of Virkon ${ }^{\circledR}-S$ on the survival of BRV

The inactivation potential of Virkon ${ }^{\circledR}$-Son BRV was studied by using different concentrations under different time intervals such as $0.5,1.0$ and $1.5 \%$ for the observations period of $0,30,60,90$ and $120 \mathrm{~min}$. With the increasing 


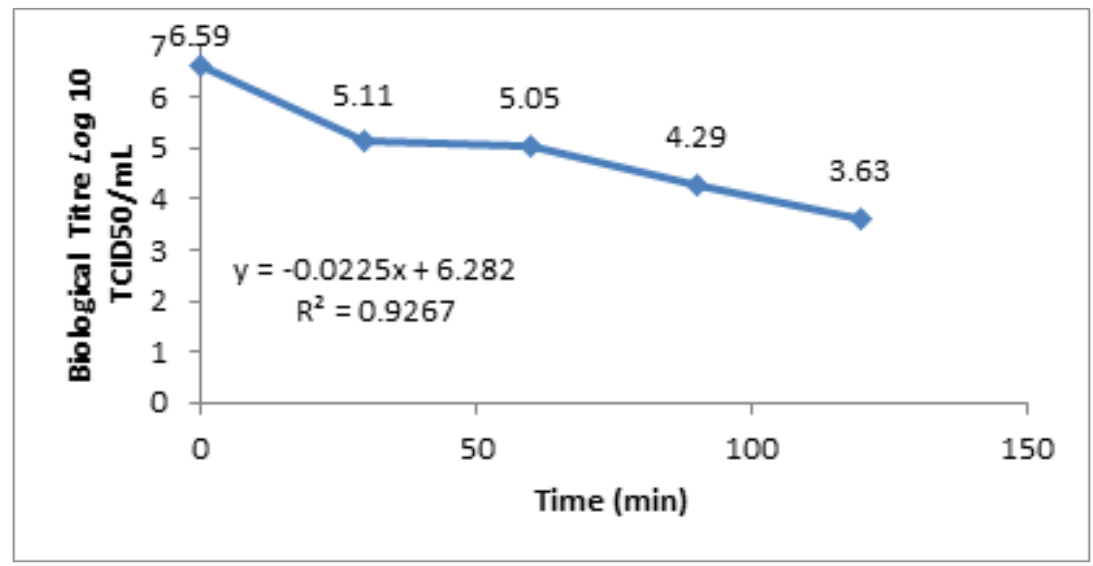

Figure 8(a). Linear regression model showing decrease in titer of BRV after treatment with $0.5 \%$ pyodine.

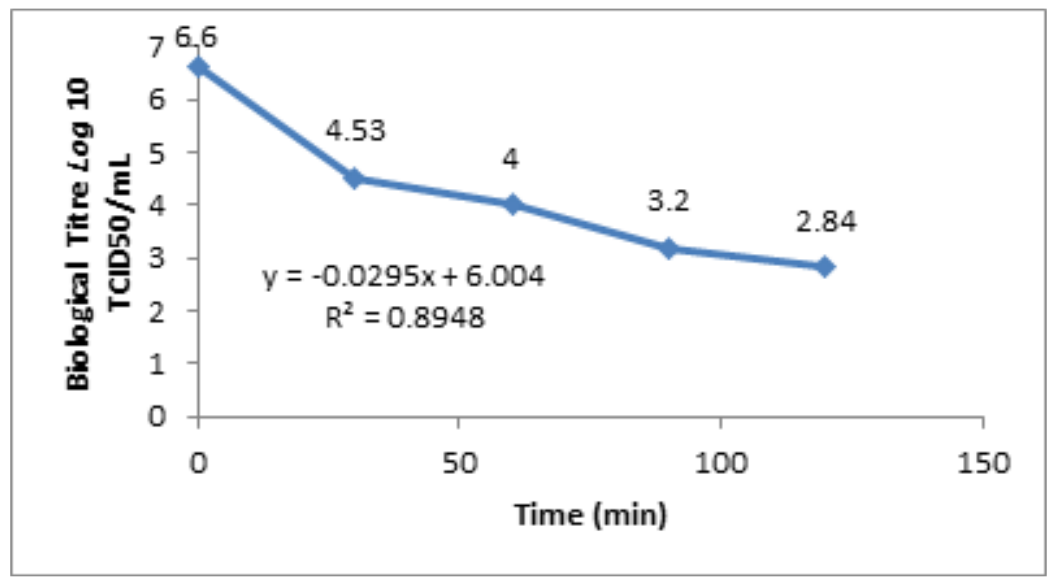

Figure $\mathbf{8}(\mathbf{b})$. Linear regression model showing decrease in titer of BRV after treatment with $1.0 \%$ pyodine.

concentration of the disinfectants, time starts decreasing (Figure 9). A magnificent decrease in the infectivity titer can be seen at $0.5 \%$ concentration of the chemical after $30 \mathrm{~min}$.

\section{Effect of Bromo-Sept on the survival of BRV}

The inactivation potential of Bromo-Sept on BRV was studied by using undiluted bromo-sept for the contact time of $30 \mathrm{~min}$. It produced $3 \log _{10}(99.9 \%)$ reduction in virus load at $0.5 \%$ concentration of Bromo-Sept after $30 \mathrm{~min}$. The behavior of Bromo-sept on the virus is given in Figure 10.

\section{Effect of Surf Excel on the survival of BRV}

The inactivation potential of Surf excel on BRV was studied by using three concentrations of the detergent such as 0.5 , 1.0 and $2.0 \%$ for the contact time of 30 to $120 \mathrm{~min}$. It produced $3 \log _{10}$ reduction in virus load. The behaviors of surf excel on the virus in given in Figure $11(a, b)$. The reduction in viral load can be seen at concentration of $1.0 \%$ after $30 \mathrm{~min}$.

\section{DISCUSSION}

Neonatal calf diarrhea represents a vital sanitary issue in livestock production which leads to an enormous negative economic influence related to reduction in weight gain of affected animals, veterinary treatment costs and death (Badaracco et al., 2013). The dissemination of disease is largely contributed by the infected animals which excretes large quantity of viruses in their fecal material, contaminating the surrounding and thus the virus spreads to susceptible population which later on ends up in outbreaks of gastroenteritis in young calves (Khan et al, 2008). 


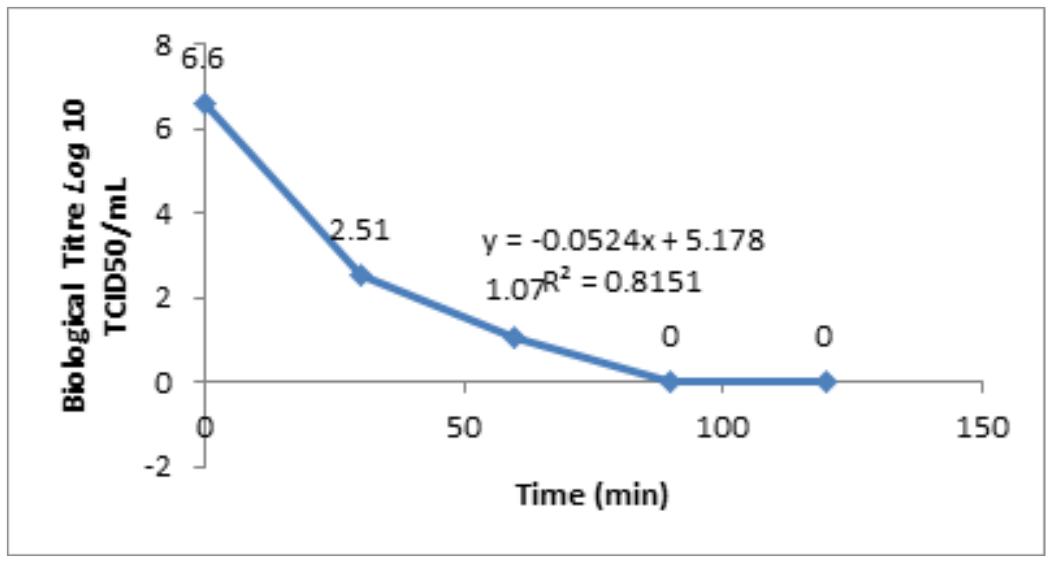

Figure 9. Linear regression model showing decrease in titer of BRV after treatment $0.5 \%$ Virkon ${ }^{\circledR}-\mathrm{S}$.

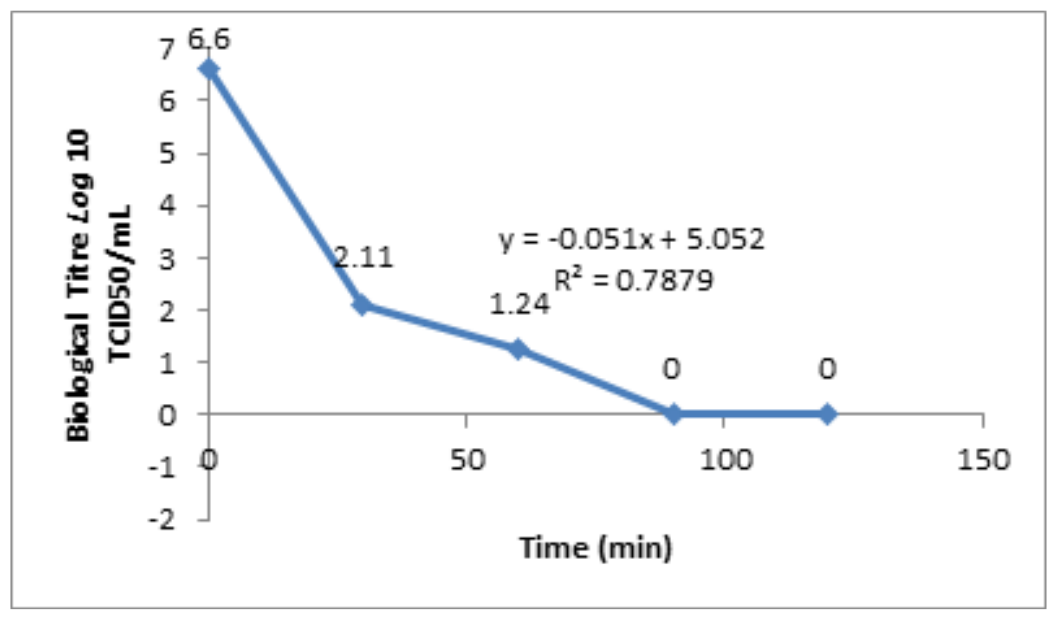

Figure 10. Linear regression model showing decrease in titer of BRV after treatment with $0.5 \%$ Bromo-sept.

Environment contributes largely in the survival and endurance of all types of organisms. Viruses being nonliving particles need a living host system for their multiplication but their existence and survival chances in the environment plays significant role in transmission to specific host (Mehle and Ravnikar, 2012). There are a number of physical (humidity, sunlight, temperature etc.) and chemical factors which affects viral survival inside and outside of the host system. Presence of organic matter (mucous, saliva, feces, blood etc.), the type of virus (enveloped or non-enveloped), and the time of exposure to the susceptible damaging agent are some of the additional and comparative features that can influence the existence of the virus in the environment (Tang, 2009).

In this present study Bovine rotavirus was procured from the culture bank of Quality Operations Laboratory, UVAS, Lahore, as fecal sample. Initial screening of the virus was done by using commercially available kit by Cypress diagnostics which employs the technique of indirect sandwich ELISA (Al-Robaiee and AI Farwchii, 2013).

After getting the virus positive by the kit the first aim was to adapt the virus on cell culture. For this purpose, the virus was propagated initially on Vero cell line on which after successive 12 passages no significant CPEs were observed, so for adapting the virus in cell culture the cell line was switched from Vero to MDBK cell line. MDBK cells are supposed to be the host cells for adapting BRV as these cells are obtained from bovine kidney cells. Furthermore, MDBK cells bear bovine carbohydrates as ligands so they neutralized any effect or hindrance occurred during virus adaptation (Reading et al, 1998). When the virus was switched to MDBK cell line a remarkable difference in the CPEs was observed and after 9 successive passages the titer of the virus was found quite sufficient for carrying further study. The titer of the virus was calculated by Reed and Meunch method of TCID 50 and was found to be $10^{6.62} / \mathrm{ml}$.

The second aim was to study the infectivity and inactivity 


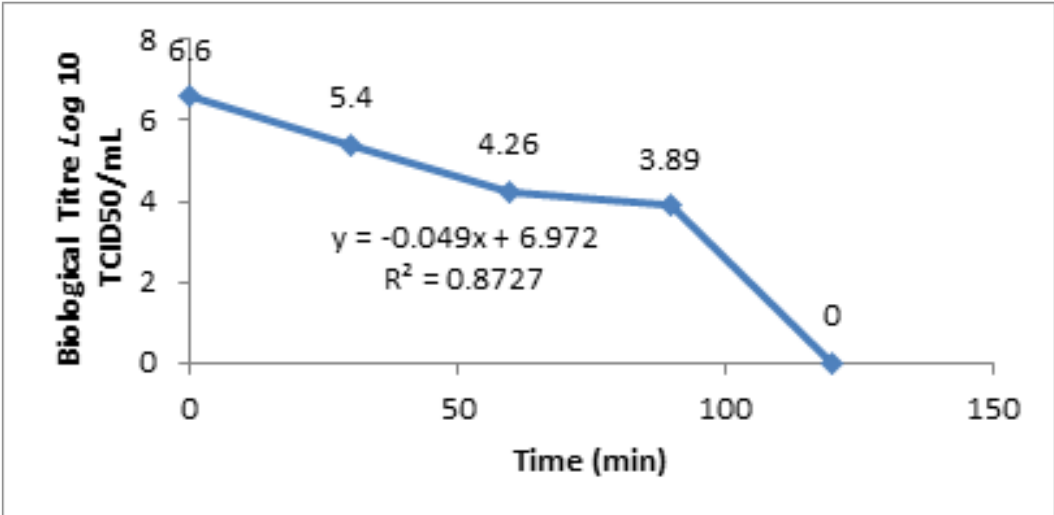

Figure 11(a). Linear regression model showing decrease in titer of BRV after treatment with $0.5 \%$ Surf excel.

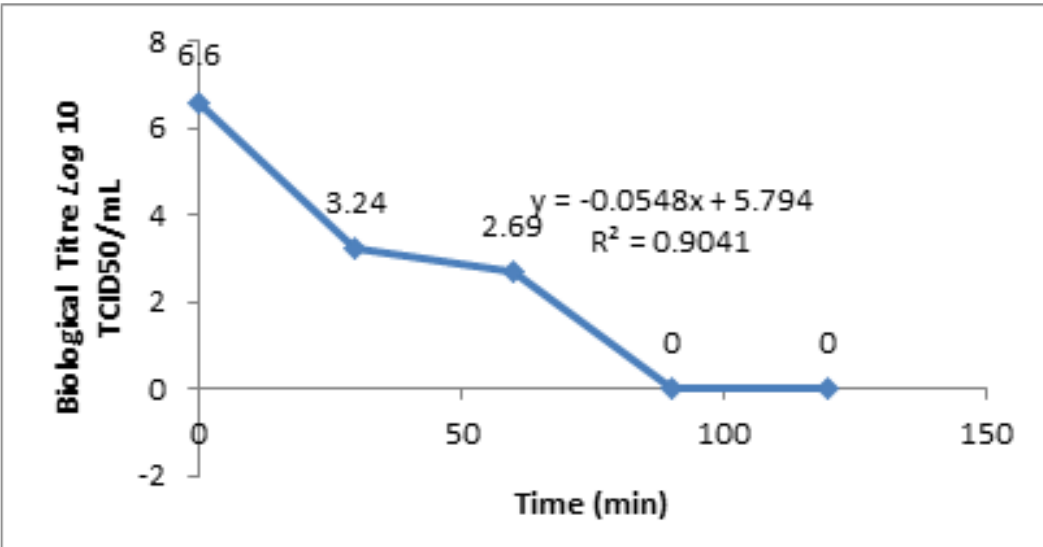

Figure 11(b). Linear regression model showing decrease in titer of BRV after treatment with $1.0 \%$ Surf excel.

pattern of the BRV. In the previous studies, the literature is concerned only for the inactivation of human rotavirus in the hospitals where it becomes the reason of nosocomial infections among the infants or the literature tells the studies of physical and chemical inactivation of different viruses (Human simian virus, adenovirus, noro virus etc). In this present study, the novelty deals with the study of inactivation of bovine rotavirus, which is also zoonotic in nature. By studying different parameters used for the inactivation of the above mentioned viruses, a set of physical and chemical factors were devised to conduct the research on this propagated virus. For this reason, 3 physical factors i.e, effect of temperature, $\mathrm{pH}$, and UV radiations was evaluated on the survival of BRV in the environment. The virus was completely inactivated at 70 , 75 and $80^{\circ} \mathrm{C}$ within the period of 15 minutes, while at 50 , 55,60 , and $65^{\circ} \mathrm{C}$ the virus infectivity was still detectable after 15, 20 and 25 min, respectively. A wide temperature range was selected to have a better insight into the survival of $\mathrm{BRV}$ at diverse environmental conditions. Being a non- enveloped virus, $\mathrm{BRV}$ is highly resistant to temperature and inactivated within $30 \mathrm{~min}$ at $80^{\circ} \mathrm{C}$ (Jiang et al, 2013). It has been estimated that high temperature ranges denature the viral proteins which ends up in the inactivation of virus, this is true in case of enveloped viruses. As far as nonenveloped viruses are concerned, high temperature causes alterations in the structural proteins (basically capsid proteins), which are left unable to retain their basic morphology and thus does not support receptor-ligand interaction and so virus stops attaching to the surface and becomes inactive (Sobsey and Meschke, 2003). However, there are some viruses that resist high temperature for a substantial period of time like enteroviruses and HAV which persist even at $70^{\circ} \mathrm{C}$ for 10 minutes and at $60^{\circ} \mathrm{C}$ for 30 minutes as compared to bacteria and parasites (Guardabassi et al., 2003).

Variation in $\mathrm{pH}$ was not found much effective to completely inactivate BRV within 2 hours, but the infectivity titers were reduced at 5.00 and 9.00 as compared to neutral $\mathrm{pH}$. The $\mathrm{pH}$ ranges below 5.0 or above 11.0 inactivates the 
virus (Anonymous 2009). In comparison to this, the studies of non-enveloped viruses showed that complete inactivation of most of the viruses occurred at or below $\mathrm{pH}$ 3 (Nims and Plavsic, 2012). However, there are certain viruses which are stable at even at highly acidic conditions, i.e, HAV which is resistant even at $\mathrm{pH} 1.00$ or 2.00 (Guardabassi et al, 2003). The mechanism of viral inactivation under the influence of $\mathrm{pH}$ is thought to be directly linked with the conformation and symmetry of the outer capsid proteins (Sobsey and Meschke, 2003). Avian viruses are enveloped viruses and are thought to be more active at low pH i.e, 6.00 to 6.4 (Shahid et al., 2009). The inactivation of virus because of the effect of $\mathrm{pH}$ might be due to the conformational changes in hemagglutinating proteins (De Benedictis et al., 2007).

Ultra Violet (UV) light at a wavelength of $253.7 \mathrm{~nm}$ is vicious for BRV like all other bacteria and viruses. The effect of UV-light on BRV, in this present study, suggests that it is detrimental to virus and inactivates it within $20 \mathrm{~min}$. The wavelength of $253.7 \mathrm{~nm}$ normally lies in the range of UV-B radiations on the spectrum, whereas, the natural sun light contains radiations of UV-A category which contains greater wavelength and low penetration power, hence, they require more time for viral inactivation (Sobsey and Meschke, 2003). UV light penetrates deep down the core of the virus where its genetic material is present and poses serious threats like dimerization of the genetic material which is an abnormality. After facing such an insult, the virus no longer remains active. UV rays present in natural light introduce structural changes in viral proteins and nucleic acid, leaving the virus inactive (Wilhelm et al., 2002).

Phenol (99.5\%: Riedel-deHaën) at the concentration of $1.0 \%$ effectively inactivated BRV within few hours but it was found to be toxicogenic for the living cells at recommended concentration for disinfection. Only the concentration of $0.5 \%$ was evaluated for results and found to inactivate the virus completely within 3 hours. So it can be inferred that at virucidal recommended concentration (2\%), it is effective to inactivate the virus within minutes (Meng et al, 1987).

As far as the alcohols are concerned, it has been reported that with the increase in carbon number of the alcohols, the effect of alcohols on viruses become evident. The more the concentration, the more virucidal tendencies it induce (Kurtz et al., 1980). In this present study, 2 alcohols were used; the one being ethanol (2 carbon atoms) and the other being isopropanol (3 carbon atoms). Ethanol (98.5\%: LABSCAN) was found to be effective against BRV at the concentration of $70 \%$ and it reduced the viral titer by $3 \log _{10}$ after 90 min, whereas, isopropanol (95\%: Riedel-deHaën) dropped the infectivity titer to this extent at the concentration of $60 \%$ after 90 min.

Hydrogen peroxide $\left(\mathrm{H}_{2} \mathrm{O}_{2}\right)(35 \%$ : MERCK) had also been employed in this study and the concentration of $0.8 \%$ had been proved to be fruitful in disinfecting the virus after 60 min. The concentration above that was proved to be cytotoxic to the cells.

Virkon®-S inactivated BRV within 30 minutes at $0.5 \%$ concentration, reducing the titer to $3 \log _{10}$ and proved to be less toxic for the living cells up to $1 \%$ concentration. The concentration of $1.5 \%$ causes cytotoxicity in the culture vessel so this concentration was not suitable for the cells as this and can damage the cells too. The Virkon $\circledast$-S at the dilution of $1: 400^{\text {th }}$ destroyed either of the two porcine viruses, i.e. Classical swine fever virus (CSFV) and PRV within the time range of 30 seconds and reduced infectivity titer from $\mathrm{TCID}_{50} 10^{5.25}$ and $10^{6.5} / \mathrm{ml}$ respectively to 0 (Bunpapong et al., 2011).

Pyodine had been found to be effective against nonenveloped viruses in previous studies (Anonymous 2009). In the present study, pyodine at the concentration of $1.0 \%$ was evaluated to be effective against BRV which tend to reduce the infectivity titer from $10^{6.62} \pm 0.11$ to $10^{2.87} \pm 0.11 / \mathrm{ml}$. The concentration of $2 \%$ was found to be toxic to the cells.

Bromo-Sept (10\%) solution was very efficient in disinfecting BRV and its concentration of $1.0 \%$ completely destroyed the viral activity after $60 \mathrm{~min}$. The concentration of $1.5 \%$ was found out to be cytotoxic.

The antiviral activity of surf excel was very efficient. The concentration of $1.0 \%$ of this commercially available product was proved to be potent for the survival of the BRV. It completely destroyed the virus after $60 \mathrm{~min}$ at this concentration.

\section{Conclusion}

Calf diarrhea has been a major disease problem in the cattle industry. The influence of this uproar on the economy of the cattle industry is still significant. Though many new strategies (e.g., vaccine, medications and herd management) have been developed and practiced to minimize the economic loss. However, physical and chemical factors have not been studied to minimize the loss of cattle due to BRV. This study had been conducted to introduce some commonly available disinfectants and surfactants along with a few physical parameters to decrease the loss caused by the virus to the cattle industry.

\section{CONFLICT OF INTEREST}

The authors declare that they have no conflict of interest.

\section{REFERENCES}

Aiyegbo, M. S., Eli, I. M., Spiller, B. W., Williams, D. R., Kim, R., Lee, D. E., Liu, T., Li, S., Stewart, P. L., \& Crowe, Jr. J. E. (2014). Differential accessibility of a Rotavirus VP6 epitope in trimers comprising type I, II, or III channels as revealed by binding of a human Rotavirus VP6-specific antibody. Journal of Virology, 88(1), 469-76.

Al-Robaiee, I. A., \& Al-Farwachi, M. I. (2013). Prevalence of rotaviral infection in diarrheic neonatal calves in Mosul city, Iraq. Veterinary World, 6(8), 538-540.

Anonymous (2009). Rinder pest. In: Technical Disease Card database, (Paris, France: OIE Office International des Epizooties/World Organization for Animal Health). 
Arias, C. F., Isa, P., Guerrero, C. A., Méndez, E., Zárate, S., López, T., Espinosa, R., Romero, P., \& López, S. (2002). Molecular biology of rotavirus cell entry. Archives of Medical Research, 33(4), 356-361.

Arnold, M., Patton, J. T., \& McDonald, S. M. (2009). Culturing, storage, and quantification of Rotaviruses. Current Protocols in Microbiology, Chapter 15: Unit 15C 3.

Badaracco, A., Garaicoechea, L., Matthijnssens, J., Uriarte, E. L., Odeón, A., Bilbao, G., Fernandez, F., Parra, G. I., \& Parreño, V. (2013). Phylogenetic analyses of typical bovine rotavirus genotypes G6, G10, P [5] and P [11] circulating in Argentinean beef and dairy herds. Infection, Genetics and Evolution, 18, 1830.

Bugarc̀ić, A., \& Taylor, J. A. (2006). Rotavirus nonstructural glycoprotein NSP4 is secreted from the apical surfaces of polarized epithelial cells. Journal of Virology, 80(24), 1234312349.

Bunpapong, N., Talummuk, S., Chaiyanate, P., Sievert, K., Thanawongnuwech, R. (2011). VirusnipTM and Virkon®S efficacy test on CSFV and PRV. Proc. Asian Pig Vet. Soc. Congress. 5: 140.

Chen, S. C., Tan, L. B., Huang, L. M., \& Chen, K. T. (2012). Rotavirus infection and the current status of Rotavirus vaccines. Journal of the Formosan Medical Association, 111(4), 183-193.

Cho, Y-il. (2012). Ecology of calf diarrhea in cow-calf operations. Graduate Theses and Dissertations. 12642. Iowa State University Capstones, Theses and Dissertations. Available at https://lib.dr.iastate.edu/etd/12642.

De Benedictis, P., Beato, M. S., \& Capua, I. (2007). Inactivation of avian influenza viruses by chemical agents and physical conditions: A review. Zoonoses and Public Health, 54(2), 5168.

Dhama, K., Chauhan, R. S., Mahendran, M., \& Malik, S. V. S. (2009). Rotavirus diarrhea in bovines and other domestic animals. Veterinary Research Communications, 33(1), 1-23.

Estes, M. K., Graham, D. Y., Smith, E. M., \& Gerba, C. P. (1979). Rotavirus stability and inactivation. Journal of General Virology, 43(2), 403-409.

Estes, M. K., Kang, G., Zeng, CQ-Y., Crawford, S. E. \& Ciarlet, M. (2001). Pathogenesis of Rotavirus gastroenteritis, Novartis Foundation Symposium. Chichester; New York; John Wiley; 1999. Pp. 82-100.

Gregersen, J. P. (2012). Decreasing potential iatrogenic risks associated with influenza vaccines. EP Patent 2, Pp. 155 \& 236.

Guardabassi, L., Dalsgaard, A., \& Sobsey, M. (2003). Occurence and survival of viruses in composted human faeces. Volume 32. (Denmark), Pp. 27-37.

Höh, H., Presser, W., \& Wigand, R. (1983). Nosokomial-Infektion durch Rotaviren bei Erwachsenen. DMW-Deutsche Medizinische Wochenschrift, 108(42), 1586-1591.

Holland, R. E. (1990). Some infectious causes of diarrhea in young farm animals. Clinical Microbiology Reviews, 3(4), 345375.

Jiang, B., Glass, R. I., \& Saluzzo, J. f. (2013). Thermal inactivation of rotavirus. US Patent, Pp. 20-384.

Kaushik, R. S., Begg, A. A., Wilson, H. L., Aich, P., Abrahamsen, M. S., Potter, A., Babiuk, L. A., \& Griebel, P. (2008). Establishment of fetal bovine intestinal epithelial cell cultures susceptible to bovine rotavirus infection. Journal of Virological Methods, 148(1-2), 182-196.

Khadre, M. A., \& Yousef, A. E. (2002). Susceptibility of human rotavirus to ozone, high pressure, and pulsed electric field. Journal of Food Protection, 65(9), 1441-1446.
Khan, M. A., Hussain, S. N., Bahadar, S., Ali, A. and Shah, I. A. (2008). An outbreak of peste des petits ruminants (PPR) in goats in district Chitral, N.W.F.P., Pakistan. ARPN Journal of Agricultural and Biological Sciences, 3.

Kurtz, J. B., Lee, T. W., \& Parsons, A. J. (1980). The action of alcohols on Rotavirus, astrovirus and enterovirus. The Journal of Hospital Infection, 1(4), 321-325.

Lopez, S., \& Arias, C. F. (2006). Early steps in Rotavirus cell entry. Current Topics in Microbiology and Immunology, 309: 39-66.

Maes, R. K., Grooms, D. L., Wise, A. G., Han, C., Ciesicki, V., Hanson, L., Vickers, M. L., Kanitz, C., \& Holland, R. (2003). Evaluation of a human group a rotavirus assay for on-site detection of bovine rotavirus. Journal of Clinical Microbiology, 41(1), 290-294.

McNulty, M. S. (1978). Rotaviruses. Journal of General Virology, 40(1), 1-18.

Mehle, N., \& Ravnikar, M. (2012). Plant viruses in aqueous environment-survival, water mediated transmission and detection. Water Research, 46(16), 4902-4917.

Meng, Z. D., Birch, C., Heath, R., \& Gust, I. (1987). Physicochemical stability and inactivation of human and simian rotaviruses. Applied and Environmental Microbiology, 53(4), 727-730.

Miles, M. G., Lewis, K. D., Kang, G., Parashar, U. D., \& Steele, A. D. (2012). A systematic review of Rotavirus strain diversity in India, Bangladesh, and Pakistan. Vaccine, 30 Suppl 1, A131139.

Nims, R. W., \& Plavsic, M. (2012). Polyomavirus inactivation - A review. Biologicals. In Press.

Pesavento, J. B., Crawford, S. E., Estes, M. K. and Prasad, B. V. (2006). Rotavirus proteins: structure and assembly. Current Topics in Microbiology and Immunology, 309, 189-219.

Ramig, R. F. (2004). Pathogenesis of intestinal and systemic rotavirus infection. Journal of Virology, 78(19), 10213-10220.

Reading, P. C., Holmskov, U., \& Anders, E. M. (1998). Antiviral activity of bovine collectins against rotaviruses. Journal of General Virology, 79(9), 2255-2263.

Shahid, M. A., Abubakar, M., Hameed, S., \& Hassan, S. (2009). Avian influenza virus ( $\mathrm{H} 5 \mathrm{~N} 1$ ); effects of physico-chemical factors on its survival. Virology Journal, 6(1), 38.

Smelt, J. (1998). Recent advances in the microbiology of high pressure processing. Trends in Food Science and Technology, 9(4), 152-158.

Sobsey, M. D., \& Meschke, J. S. (2003). Virus survival in the environment with special attention to survival in sewage droplets and other environmental media of fecal or respiratory origin. Report for the World Health Organization, Geneva, Switzerland, 70.

Swayne, D. E., Glisson, J. R., Reed, W. M., \& Pearson, J. E. (2006). A Laboratory Manul for the Isolation and Identification of Avian Pathogens, 4 Ed, International Book Distributing Company.

Swiatek, D. L., Palombo, E. A., Lee, A., Coventry, M. J., Britz, M. L., \& Kirkwood, C. D. (2010). Detection and analysis of bovine rotavirus strains circulating in Australian calves during 2004 and 2005. Veterinary Microbiology, 140(1-2), 56-62.

Tang, J. W. (2009). The effect of environmental parameters on the survival of airborne infectious agents. Journal of the Royal Society Interface, 6(suppl. 6), S737-S746.

Wilhelm, S. W., Jeffrey, W. H., Suttle, C. A., \& Mitchell, D. L. (2002). Estimation of biologically damaging UV Levels in marine surface waters with DNA and viral dosimeters. Photochemistry and Photobiology, 76(3), 268-273. 